\title{
PERANCANGAN DAN PEMBUATAN SERTA PENGUJIAN (KELAYAKAN) KEBERFUNGSIAN ALAT MENGUKUR SUHU FLUIDA PADA PRAKTIKUM SUHU DAN KALOR
}

\author{
Herlina Lanto, Marianus, Jeane Cornelda Rende \\ Fakultas Matematika dan Ilmu Pengetahuan Alam, Universitas Negeri Manado \\ email: herlinalanto090@gmail.com
}

\begin{abstract}
ABSTRAK
Penelitian ini dilatar belakangi kurangnya ketersediaan alat dan penuntun praktikum mengukur suhu fluida yang menyebabkan kegiatan praktikum tidak dapat dilaksanakan. Tujuan dari penelitian ini adalah menghasilkan alat mengukur suhu fluida yang layak digunakan dalam kegiatan praktikum di laboratorium fisika UNIMA. Penelitian ini merupakan penelitian pengembangan (Research and Development) yang terdiri dari beberapa tahapan penelitian yaitu kajian awal, kajian literatur, perancangan alat praktikum, pembuatan alat praktikum, validasi pakar/ ahli, revisi 1 (perbaikan 1), uji keberfungsian, validasi pakar/ ahli, revisi 2 (perbaikan 2) dan pelaporan. Pengambilan data dilakukan dengan eksperimen, validasi pakar/ ahli. Hasil pengujian alat praktikum mengukur suhu fluida ini memiliki persentase kesalahan paling tinggi 2,3\% sedangkan validasi ahli materi dan ahli media untuk alat dan penuntun praktikum mengukur suhu fluida berada pada kriteria $90-100 \%$. Berdasarkan hasil penelitian dapat disimpulkan bahwa telah dihasilkan alat dan penuntun praktikum mengukur suhu fluida dengan kualifikasi valid atau layak.
\end{abstract}

Kata kunci : Alat praktikum, Mengukur suhu fluida, penuntun praktikum.

\section{ABSTRACT}

This research was motivated by the lack of availability of tools and practical guides for measuring fluid temperature, which made it impossible to conduct practical activities. The aim of this research is to develop a tool for measuring liquid temperature that is suitable for practical activities in the UNIMA physics laboratory. This research is a research development (research and development) that consists stages, namely preliminary studies, literature research, design of internship tools, production of internship tools, validation of experts/ experts, revision 1 (improvement 1), functionality test, validation of experts/ emperts, revision 2 (improvement 2) and reporting. The data was collected through experiment and expertvalidation. The test results of the practical tool for measuring the temperature of this liquid show the highest percentage of errors at 2,3\%, while the validation by materials experts and media experts for tools and practical guides for measuring the liquid temperature is in the range of 90-100\%. Based on the results of the study, it can be concluded that a tool and practical guide for measuring fluid temperature with valid or proper qualifications has been created.

Keywords : Practicum tools, liquid temperature measurement, practicum instruction 


\section{PENDAHULUAN}

Pendidikan adalah usaha sadar yang dilakukan secara teratur dalam mewujudkan suasana belajar mengajar sehingga peserta didik dapat mengembangkan potensi dalam dirinya. Sebagai seorang pendidik, guru harus mampu mengembangkan potensi peserta didik dan kreativitas peserta didik. Oleh sebab itu, guru mempunyai peranan yang besar dalam proses belajar mengajar, sehingga dituntut memiliki berbagai kemampuan dalam usaha meningkatkan mutu pendidikan. Guru berperan sebagai fasilitator yang akan memfasilitasi peserta didik dalam belajar sehingga peserta didik yang akan aktif belajar dari berbagai sumber belajar. Salah satu sumber belajar yang diharapkan mampu memberikan sistem belajar yang berpusat pada peserta didik ialah penggunaan media dalam kegiatan pembelajaran.

Penggunaan media pembelajaran bertujuan untuk menyampaikan pesan dari pendidik agar dapat di pahami dengan baik oleh peserta didik sehingga proses belajar yang di alami oleh peserta didik bukan hanya sekedar menghafal tetapi lebih kepemahaman tentang materi yang di sampaikan oleh pendidik. Media sebagai alat bantu apa saja yang dapat di jadikan sebagai wahana penyalur informasi belajar atau penyebar pesan guna mencapai tujuan pembelajaran (Djamarah \& Aswan dalam Muhson, 2010). Dengan menggunakan media pembelajaran dalam proses belajar dapat membantu memperlancar interaksi antara pendidik dengan peserta didik sehingga kegiatan pembelajaran akan lebih efektif dan efesien.

Sains atau Ilmu Pengetahuan Alam merupakan bagian dari ilmu yang mempelajari tentang alam semesta, bagian-bagian yang ada di permukaan bumi, di perut bumi dan diluar angkasa. Baik yang dapat diamati maupun yang tidak dapat di amati. IPA (sains) terbagi atas beberapa cabang ilmu diantaranya adalah fisika. Fisika adalah ilmu pengetahuan yang didalamnya mempelajari tentang sifat dan fenomena alam atau gejala alam dan seluruh interaksi yang terjadi.

Kegiatan praktikum laboratorium memiliki peran penting secara khusus sebagai pusat dalam menggali cara berpikir dan kegiatan memperoleh suatu data melalui proses pengamatan. Sesuai dengan karakteristiknya fisika merupakan sekumpulan keterampilan dasar yang mencerminkan proses dalam tujuan ilmiah. (Sutrisno dalam Maharani, 2016). Kegiatan praktikum memberikan peran sangat besar dalam membangun pemahaman konsep, menumbuhkan keterampilan proses secara efektif bagi peserta didik, menumbuhkan motivasi pelajaran dan melatih kemampuan psikomotor.

Suatu alat praktikum, harus mampu menjelaskan konsep fisika dan aplikasinya dalam kehidupan sehari-hari. Melalui eksperimen, suatu alat praktikum dapat menguji teori yang ada. Selain alat, panduan praktikum juga sangat berpengaruh dalam menunjang keberhasilan dalam suatu kegiatan praktikum. Panduan praktikum merupakan pedoman pelaksanaan praktikum yang berisi tata cara persiapan, pelaksanaan kegiatan praktikum, analisis dan pengolahan data serta pelaporan kegiatan praktikum. Hal ini yang membuat panduan dalam sebuah praktikum harus di buat dalam keadaan optimal sehingga dapat memenuhi semua komponen praktikum yang di uji cobakan dalam laboratorium. Penggunaan alat dan panduan praktikum merupakan salah satu alternatif yang dapat di gunakan untuk memudahkan peserta didik dalam memahami materi apabila di gunakan dengan baik.

Hasil observasi di Laboratorium Fisika UNIMA di peroleh informasi bahwa kurangnya ketersediaan alat dan penuntun praktikum pada materi suhu dan kalor yaitu untuk mengukur suhu fluida sehingga menyebabkan kegiatan praktikum tidak dilaksanakan. Kurangnya ketersediaan alat praktikum disebabkan karena manajemen laboratorium yang kurang maksimal dan faktor usia dari alat praktikum yang sudah berumur puluhan tahun menyebabkan alat-alat praktikum menjadi rusak dan tidak dapat di gunakan.

Upaya untuk mengatasi masalah ketersediaan alat praktikum mengukur suhu fluida yaitu perlu adanya perancangan dan pembuatan alat praktikum yang akan menunjang kegiatan praktikum di Laboratorium Fisika UNIMA. Pembuatan alat praktikum dengan menggunakan bahan-bahan yang mudah ditemukan dan harganya cukup terjangkau sehingga sumber dana yang dibutuhkan tidaklah terlalu besar, namun alat 
praktikum yang dibuat dapat berfungsi dengan baik. Perancangan adalah tahapan mendesain sistem baru yang dapat menyelesaikan masalah-masalah yang dihadapi yang di peroleh dari pemilihan alternatif sistem yang terbaik (Ladjamudin, 2005). Adanya perancangan dan pembuatan alat dan penuntun praktikum mengukur suhu fluida, peneliti berharap peserta didik di jurusan fisika UNIMA dapat melaksanakan kegiatan praktikum fisika dasar mengukur suhu fluida.

\section{Mengukur Suhu Fluida}

Suhu adalah besaran yang menyatakan derajat panas atau dingin suatu benda. Suhu menunjukkan derajat panas benda. Mudahnya, semakin tinggi suhu suatu benda, semakin panas benda tersebut. Kalor atau panas merupakan salah satu bentuk energi. Kalor sebagai bentuk energi yang berpindah dari benda yang bersuhu lebih tinggi ke benda yang bersuhu lebih rendah ketika kedua benda bersentuhan satu sama lain sampai keduanya sama dan kesetimbangan termal tercapai. Pengaruh kalor terhadap suatu benda dapat menaikan suhu dan mengubah wujud benda. Jika memberikan kalor yang sama dalam waktu yang sama pada benda yang berbeda, perubahan suhu kedua benda tersebut belum tentu sama, ini berarti perubahan suhu dipengaruhi oleh jenis benda. Hal ini terjadi karena tiap benda memiliki kalor jenis (c) yang berbeda-beda.

$$
\begin{gathered}
\Delta \mathrm{T}=\frac{\mathrm{Q}}{\mathrm{mc}} \\
\mathrm{Q}=\mathrm{mc} \Delta \mathrm{T}
\end{gathered}
$$

Pada proses pemanasan fluida diperluhkan sejumlah kalor untuk menaikkan suhunya. Untuk menghitung energi kalor yang diberikan pemanas dan kalor yang diterima fluida digunakan persamaan :

$$
\begin{aligned}
\mathrm{Q}_{\text {pemanas }} & =\frac{\mathrm{m}_{\text {pemanas }} \times \mathrm{c}_{\mathrm{p}_{\text {pemanas }} \times \Delta \mathrm{T}}}{\Delta \mathrm{t}} \\
\mathrm{Q}_{\text {fluida }} & =\frac{\mathrm{m}_{\text {fluida }} \times \mathrm{c}_{\mathrm{p}_{\text {fluida }} \times \Delta \mathrm{T}}}{\Delta \mathrm{t}}
\end{aligned}
$$

\section{METODE PENELITIAN Rancangan Penelitian}

Penelitian ini menggunakan penelitian dan pengembangan atau Research and Development $(R \& D)$. Prosedur penelitian dalam $R \& D$ menggunakan tahapan dari Borg \& Gall yang telah di modifikasi oleh
Sugiyono. Rancangan penelitian ini meliputi: kajian awal, kajian literatur, perancangan alat praktikum, pembuatan alat praktikum, uji validasi awal oleh pakar/ ahli, revisi I (perbaikan 1), uji coba penggunaan (keberfungsian), revisi II (perbaikan II) dan pembuatan laporan.

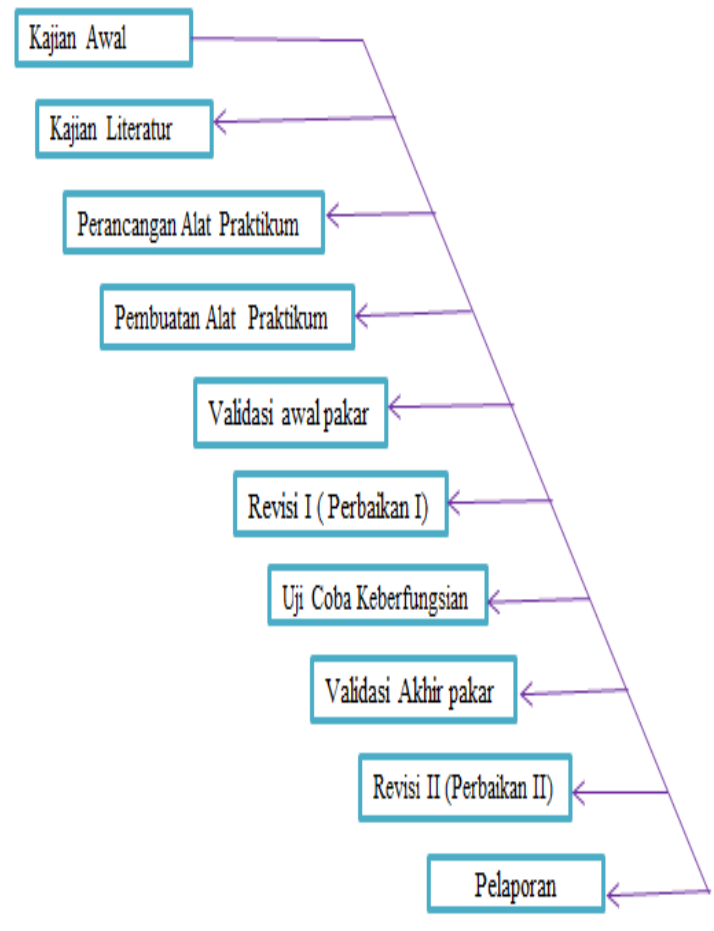

Gambar 1. Diagram Alir Kegiatan Penelitian

\section{Teknik Pengumpulan Data}

Teknik pengumpulan data untuk alat praktikum yang dikembangkan menggunakan dua cara yaitu menggunakan lembar validasi pakar/ ahli dan uji coba mandiri. Uji coba mandiri yaitu peneliti melakukan pengambilan data langsung terhadap alat praktikum mengukur suhu fluida yang dikembangkan sedangkan validasi pakar/ ahli merupakan teknik untuk memvalidasi atau menilai kelayakan rancangan alat dan penuntun praktikum, dilakukan evaluasi oleh 1 dosen ahli materi dan 1 dosen ahli ahli media.

\section{Analisis Data}

Teknik analisis data untuk alat praktikum mengukur suhu fluida yang dikembangkan menggunakan persamaan kalor yang diterima pemanas dan kalor yang diterima fluida. Analisis data untuk lembar validasi pakar/ ahli menggunakan rumus persentase kelayakan yang kemudian di sesuaikan dengan tabel kriteria tingkat kelayakan produk. 


\section{HASIL DAN PEMBAHASAN}

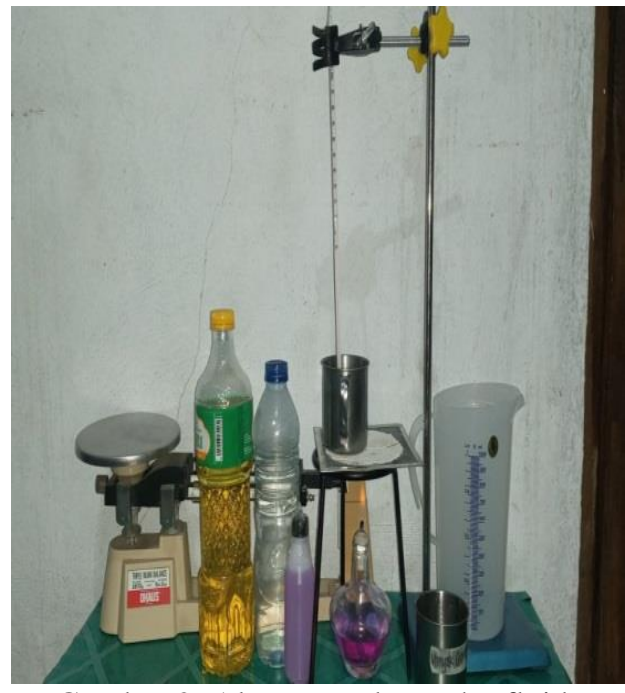

Gambar 2. Alat mengukur suhu fluida

Uji keberfungsian untuk alat praktikum mengukur suhu fluida menetapkan tiga variabel diantaranya variabel terikat jumlah kalor (Q), variabel bebas kenaikan suhu, Variabel kontrol Jenis Fluida, waktu (t). Hasil pengolahan data untuk percobaan mengukur suhu fluida disajikan dalam bentuk grafik berikut.

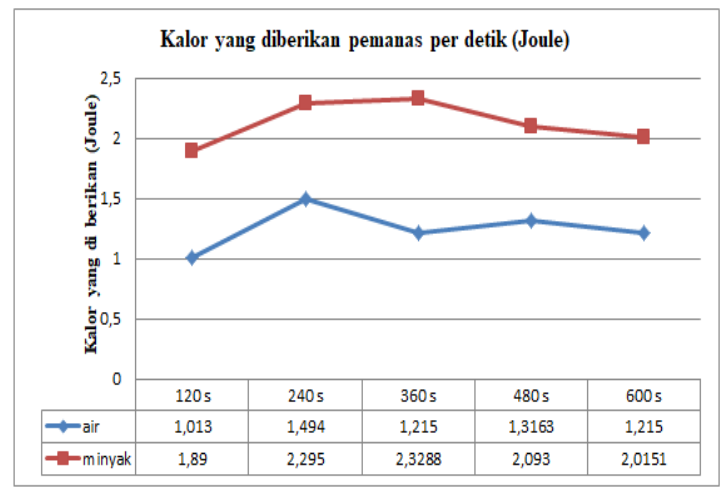

Gambar 3. Grafik banyaknya kalor yang diberikan pemanas per detik pada percobaan pertama

Dari gambar 3 terlihat adanya perbedaan kalor yang diberikan pemanas per detik pada dua jenis fluida yang berbeda, dengan massa pemanas yaitu $0,027 \mathrm{Kg}$ dan terbuat dari bahan aluminium dengan kalor jenis $900 \mathrm{~J} /{ }^{\circ} \mathrm{C}$. Kalor yang diberikan pemanas per detik paling besar terdapat pada minyak goreng pada waktu 360 sekon yaitu sebesar 2,3288 Joule sedangkan kalor yang diberikan pemanas paling kecil yaitu pada waktu 120 sekon sebesar 1,89 Joule. Besarnya kalor yang diberikan pemanas pada waktu 360 sekon disebabkan oleh perubahan suhu pada waktu ini paling besar dibandingkan pada waktu 120 s, 240 s, 480 s dan 600 s. Sedangkan pada fluida yang lain yaitu air kalor yang diberikan pemanas paling besar yaitu pada waktu 240 sekon yaitu 1,494 Joule sedangkan kalor yang diberikan pemanas paling kecil yaitu pada waktu 120 sekon sebesar 1,013 Joule.Besarnya kalor yang diberikan pemanas pada waktu 240 sekon disebabkan oleh perubahan suhu pada waktu ini lebih besar dari pada waktu $120 \mathrm{~s}, 360 \mathrm{~s}, 480 \mathrm{~s}$ dan 600 s. Berdasarkan hasil pengukuran banyaknya kalor yang diberikan pemanas per detik pada fluida pada percobaan pertama yang dilakukan sebanyak tiga kali, dengan menggunakan rumus kesalahan relatif di dapat persetanse kesalahan di sajikan dalam bentuk tabel 1 .

Tabel 1. Pengukuran banyaknya kalor yang diberikan pemanas per detik pada fluida pada percobaan pertama

\begin{tabular}{|c|c|c|c|}
\hline$\Delta t(s)$ & $\begin{array}{c}\text { Jenis } \\
\text { Fluida }\end{array}$ & $\begin{array}{l}\boldsymbol{Q}=(\boldsymbol{Q}+\overline{\boldsymbol{Q}}) \\
(\mathbf{J})\end{array}$ & $K R(\%)$ \\
\hline \multirow[t]{2}{*}{$120 \mathrm{~s}$} & Air & 1,013 & 1,35 \\
\hline & $\begin{array}{c}\text { Minyak } \\
\text { goreng }\end{array}$ & 1,89 & 1,82 \\
\hline \multirow[t]{2}{*}{$240 \mathrm{~s}$} & Air & 1,494 & 2 \\
\hline & $\begin{array}{c}\text { Minyak } \\
\text { goreng }\end{array}$ & 2,295 & 1,5 \\
\hline \multirow[t]{2}{*}{$360 \mathrm{~s}$} & Air & 1,215 & 1,124 \\
\hline & $\begin{array}{c}\text { Minyak } \\
\text { goreng }\end{array}$ & 2,328 & 1,47 \\
\hline \multirow[t]{2}{*}{$480 \mathrm{~s}$} & Air & 1,316 & 1,563 \\
\hline & $\begin{array}{c}\text { Minyak } \\
\text { goreng }\end{array}$ & 2,093 & 1,64 \\
\hline \multirow[t]{2}{*}{$600 \mathrm{~s}$} & Air & 1,215 & 1,124 \\
\hline & $\begin{array}{c}\text { Minyak } \\
\text { goreng }\end{array}$ & 2,015 & 1,198 \\
\hline
\end{tabular}

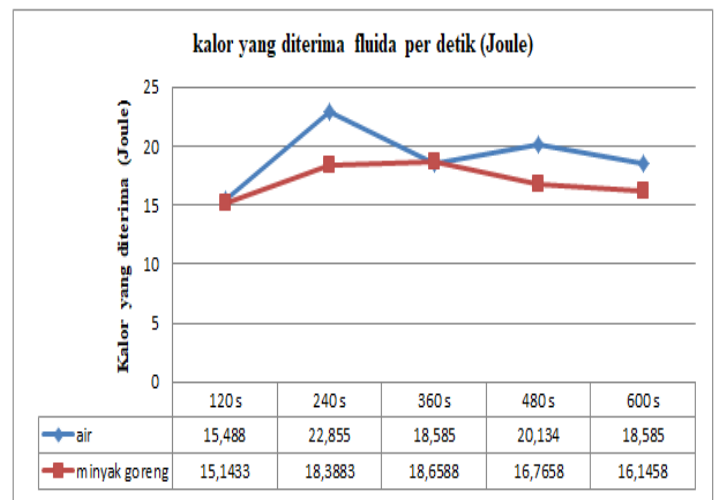

Gambar 4. Grafik kalor yang diterima fluida per detik pada percobaan pertama 
Pada gambar 4 terlihat bahwa adanya perbedaan kalor yang diterima fluida per detik dengan massa fluida yaitu $0,0885 \mathrm{Kg}$ dan mempunyai kalor jenis yang berbeda jika pada air kalor jenisnya yaitu sebesar 4.200 Joule sedangkan pada minyak goreng 2.200 Joule, fluida yang menerima kalor per detik paling besar adalah pada air yaitu 22,855 Joule pada waktu 240 sekon dan kalor yang diterima air paling kecil yaitu pada waktu 120 sekon yaitu sebesar 15,488 Joule. Besarnya kalor yang diterima oleh air pada waktu 240 sekon disebabkan oleh pada waktu ini perubahan suhunya lebih besar daripada pada waktu 120 sekon, 360 sekon, 480 sekon dan juga 600 sekon. Sedangkan pada minyak goreng kalor yang diterima paling besar yaitu pada waktu 360 sekon sebesar 18,6588 Joule.

Berdasarkan hasil pengukuran banyaknya kalor yang diterima fluida per detik pada percobaan pertama yang dilakukan sebanyak tiga kali, dengan menggunakan rumus kesalahan relatif di dapat persetanse kesalahan di sajikan dalam bentuk tabel 2 .

Tabel 2. Banyaknya kalor yang diterima fluida per detik pada percobaan pertama

\begin{tabular}{|c|c|c|c|}
\hline$\Delta t(s)$ & $\begin{array}{l}\text { Jenis } \\
\text { Fluida }\end{array}$ & $\begin{array}{l}\boldsymbol{Q}=(\boldsymbol{Q}+\overline{\boldsymbol{Q}}) \\
(\mathbf{J})\end{array}$ & $K R(\%)$ \\
\hline \multirow[t]{2}{*}{$120 \mathrm{~s}$} & Air & 15,488 & 1,35 \\
\hline & $\begin{array}{c}\text { Minyak } \\
\text { goreng }\end{array}$ & 15,143 & 1,82 \\
\hline \multirow[t]{2}{*}{$240 \mathrm{~s}$} & Air & 22,855 & 2 \\
\hline & $\begin{array}{c}\text { Minyak } \\
\text { goreng }\end{array}$ & 18,3883 & 1,49 \\
\hline \multirow[t]{2}{*}{$360 \mathrm{~s}$} & Air & 18,585 & 1,12 \\
\hline & $\begin{array}{c}\text { Minyak } \\
\text { goreng }\end{array}$ & 18,6588 & 1,28 \\
\hline \multirow[t]{2}{*}{$480 \mathrm{~s}$} & Air & 20,134 & 1,56 \\
\hline & $\begin{array}{c}\text { Minyak } \\
\text { goreng }\end{array}$ & 16,7658 & 1,47 \\
\hline \multirow[t]{2}{*}{$600 \mathrm{~s}$} & Air & 18,585 & 1,12 \\
\hline & $\begin{array}{c}\text { Minyak } \\
\text { goreng }\end{array}$ & 16,1458 & 1,198 \\
\hline
\end{tabular}

Pada gambar 5 terlihat adanya perbedaan kalor yang diberikan pemanas pada fluida per detik, dengan massa pemanas yaitu $0,027 \mathrm{Kg}$ dan terbuat dari bahan aluminium dengan kalor jenisnya 900 Joule dan massa fluida sebesar $0,1445 \mathrm{Kg}$, kalor yang di berikan pemanas pada fluida yang paling besar yaitu pada minyak goreng sebesar 1,56 Joule pada waktu ke 360 sekon sedangkan yang paling kecil yaitu pada waktu ke 120 sekon sebesar
1,04 Joule. Perubahan suhu pada waktu 360 sekon yang lebih besar dari pada waktu 240 sekon, 480 sekon dan 600 sekon sehingga menyebabkan kalor yang diberikan pemanas lebih besar. Pada air kalor yang diberikan pemanas yang paling besar yaitu pada waktu 120 sekon, 480 sekon dan 600 sekon yaitu sebesar 0,837 Joule sedangkan pada waktu 120 sekon kalor yang diberikan pemanas pada air paling kecil yaitu 0,6075 Joule, ini disebabkan oleh perubahan suhu yang lebih besar terdapat pada waktu ke 240 sekon, 480 sekon dan 600 sekon.

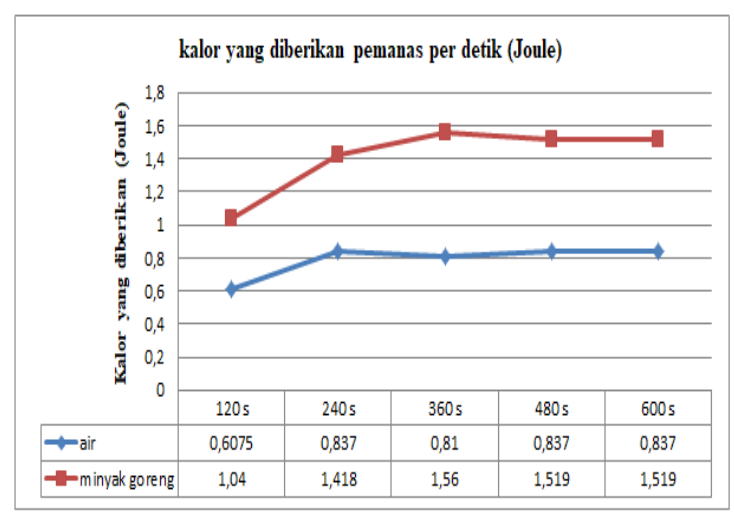

Gambar 5. Grafik kalor yang diberikan pemanas per detik pada percobaan kedua

Berdasarkan hasil pengukuran banyaknya kalor yang diberikan pemanas pada fluida pada percobaan kedua yang dilakukan sebanyak tiga kali, dengan menggunakan rumus kesalahan relatif di dapat persetanse kesalahan di sajikan dalam bentuk tabel 3 .

Tabel 3. Banyaknya kalor yang diberikan pemanas per detik pada fluida pada percobaan kedua

\begin{tabular}{|c|c|c|c|}
\hline$\Delta t(s)$ & $\begin{array}{l}\text { Jenis } \\
\text { Fluida }\end{array}$ & $\begin{array}{l}\boldsymbol{Q}=(\boldsymbol{Q}+\overline{\boldsymbol{Q}}) \\
(\mathbf{J})\end{array}$ & $K R(\%)$ \\
\hline \multirow[t]{2}{*}{$120 \mathrm{~s}$} & Air & 0,6075 & 2,27 \\
\hline & $\begin{array}{c}\text { Minyak } \\
\text { goreng }\end{array}$ & 1,0395 & 1,32 \\
\hline \multirow[t]{2}{*}{$240 \mathrm{~s}$} & Air & 0,837 & 1,64 \\
\hline & $\begin{array}{c}\text { Minyak } \\
\text { goreng }\end{array}$ & 1,4175 & 0,96 \\
\hline \multirow[t]{2}{*}{$360 \mathrm{~s}$} & Air & 0,81 & 1,7 \\
\hline & $\begin{array}{c}\text { Minyak } \\
\text { goreng }\end{array}$ & 1,56 & 1,32 \\
\hline \multirow[t]{2}{*}{$480 \mathrm{~s}$} & Air & 0,837 & 1,64 \\
\hline & $\begin{array}{c}\text { Minyak } \\
\text { goreng }\end{array}$ & 1,52 & 1,35 \\
\hline \multirow[t]{2}{*}{$600 \mathrm{~s}$} & Air & 0,837 & 1,64 \\
\hline & $\begin{array}{c}\text { Minyak } \\
\text { goreng }\end{array}$ & 1,52 & 1,35 \\
\hline
\end{tabular}




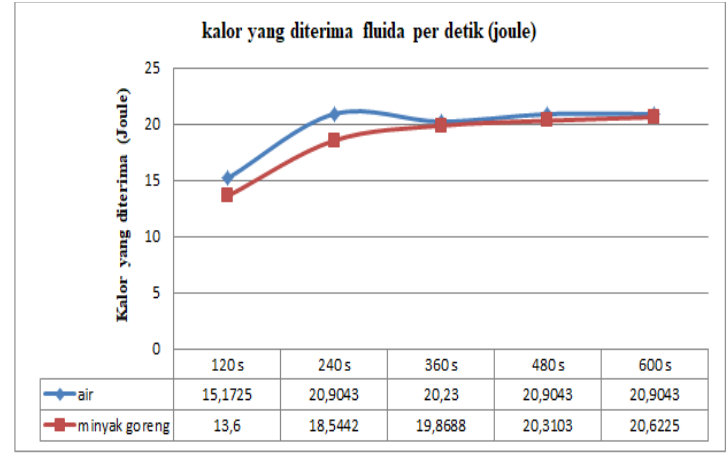

Gambar 6. Grafik banyaknya kalor yang diterima fluida per detik pada percobaan kedua

Pada gambar 6. terlihat bahwa ada perbedaan kalor yang diterima oleh fluida per detiknya. Kalor yang diterima fluida yang paling besar yaitu pada air yaitu sebesar 20,9043 Joule pada waktu ke 240 sekon dan kalor yang diterima fluida yang paling kecil yaitu pada waktu 120 sekon yaitu 15,1725 Joule. Kalor yang diterima air pada waktu 240 sekon perubahan suhunya lebih besar daripada pada waktu ke ke 120 sekon, 360 sekon, 480 sekon maupun 600 sekon. Sedangkan pada minyak goreng kalor yang diterima per detik yang paling besar yaitu pada waktu 600 sekon yaitu sebesar 20,6225 Joule, sedangkan yang paling kecil menerima kalor yaitu pada waktu 120 sekon yaitu 13,6 Joule. Hal ini disebabkan oleh perubahan suhu yang besar pada waktu ke 600 sekon dibandingkan dengan pada waktu 120 sekon, 240 sekon, 360 sekon, dan 480 sekon.

Berdasarkan hasil pengukuran banyaknya kalor yang diterima fluida per detik pada percobaan kedua yang dilakukan sebanyak tiga kali, dengan menggunakan rumus kesalahan relatif di dapat persetanse kesalahan di sajikan dalam bentuk tabel 4 .

Tabel 4. banyaknya kalor yang diterima fluida per detik pada percobaan kedua

\begin{tabular}{cccc}
\hline$\Delta \boldsymbol{t}(\boldsymbol{s})$ & Jenis & $\begin{array}{l}\boldsymbol{Q}=(\boldsymbol{Q}+\overline{\boldsymbol{Q}}) \\
(\mathbf{J})\end{array}$ & $K R(\%)$ \\
\hline $120 \mathrm{~s}$ & Aluida & 15,173 & 2,3 \\
& Minyak & 13,6 & 1,32 \\
& goreng & & \\
$240 \mathrm{~s}$ & Air & 20,9043 & 1,64 \\
& Minyak & 18,5442 & 0,962 \\
& goreng & & \\
$360 \mathrm{~s}$ & Air & 20,23 & 1,7 \\
& Minyak & 19,8688 & 1,32 \\
& goreng & & \\
$480 \mathrm{~s}$ & Air & 20,9043 & 1,64 \\
\hline
\end{tabular}

\begin{tabular}{|c|c|c|c|}
\hline \multirow{3}{*}{$600 \mathrm{~s}$} & $\begin{array}{c}\text { Minyak } \\
\text { goreng }\end{array}$ & 20,3103 & 1,32 \\
\hline & Air & 20,9043 & 1,64 \\
\hline & $\begin{array}{c}\text { Minyak } \\
\text { goreng }\end{array}$ & 20,6225 & 1,32 \\
\hline
\end{tabular}

Dari hasil analisis data maka di dapatkan bahwa perbedaan jumlah kalor yang yang diberikan pemanas maupun kalor yang diterima oleh fluida bergantung pada jenis fluida, massa dan juga perubahan suhu. Jika suhu fluida besar maka kalor yang diberikan maupun yang diterima juga besar, begitu juga sebaliknya jika suhu fluida kecil maka kalor yang diberikan maupun yang diterima juga kecil. Dapat dilihat bahwa air menerima lebih besar kalor ketika dipanaskan dengan lama pemanasan yang sama yaitu dua menit dan massa fluida yang sama daripada minyak goreng hal ini disebabkan oleh kalor jenis air lebih besar daripada kalor jenis minyak goreng. Dimana hal ini selaras dengan (Giancoli, 2014) yang menyatakan jenis zat berpengaruh terhadap jumlah kalor. Zat yang kalor jenisnya tinggi mampu menyerap kalor lebih banyak untuk kenaikan suhu yang rendah. Namun kalor yang di berikan pemanas lebih besar pada minyak goreng daripada air. Hal ini disebabkan oleh kalor jenis minyak goreng lebih kecil daripada air sehingga kenaikan suhu pada minyak goreng lebih tinggi daripada air.

Tim pakar ahli materi melakukan penilaian sebanyak 1 kali pada Penilaian oleh pakar ahli materi didapatkan persentase kelayakan sebesar 95\% sudah termasuk dalam kriteria sangat baik. Dan untuk kelengkapan rancangan penuntun berdasarkan tujuan yang ingin dicapai yaitu sebesar $100 \%$. Pada tim pakar ahli media pada validasi pertama memperoleh persentase kelayakan yaitu sebesar 75\% dikategorikan layak namun harus diperbaiki kembali dengan menambahkan kembali pengembanganya karena pada percobaan peneliti hanya menentukan hubungan antara waktu dengan kenaikan suhu serta hubungan perubahan suhu dengan massa zat sehingga pakar/ ahli media menambahkan untuk perlu di tambahkan kembali pengembangannya dan juga kesalahan relatifnya harus dihitung. Pada penilaian validasi akhir ahli media peroleh persentase kelayakan 91\% sehingga alat dan penuntun praktikum dikatakan sudah valid karena 
berada pada kriteria 90\% - 100\%.

Berdasarkan skor yang diperoleh dari uji validasi dari tim ahli maka alat dan penuntun praktikum mengukur suhu fluida dapat digunakan dalam kegiatan praktikum. Hasil dari penilaian dari tim ahli ini juga didukung dengan hasil uji coba keberfungsian yang dilakukan melalui kelompok kecil yang terdiri dari 5 mahasiswa dengan menggunakan alat dan penuntun praktikum yang telah dibuat. Hasil uji coba yang dilakukan oleh kelompok kecil ini menunjukan bahwa alat dan penuntun praktikum berfungsi dengan baik dan simpangan hasil pengukuran cukup kecil.

\section{KESIMPULAN}

Berdasarkan kajian teori, pengolahan data dan hasil penelitian maka dapat disimpulkan bahwa alat dan penuntun praktikum mengukur suhu fluida pada praktikum suhu dan kalor layak di gunakan untuk kegiatan praktikum fisika dasar karena telah diuji keberfungsian alat dan penuntun praktikum serta validasi dari ahli/ pakar materi dan ahli pakar/ media.

\section{REFERENSI}

Giancoli, D. (2001). Fisika Dasar Edisi Ke V. Jakarta: Erlangga.

Ladjamudin. (2005). Analisis dan Desain Sistem Informasi.

Maharani, G. (2016). Model Gi-Gi pada hasil belajar dalam pembelajaran fisika (materi teori kinetik gas) di SMA. Jurnal Pembelajaran Fisika.

Marianus, Jeane R., \& Ni Kadek J. (2020). Pengembangan alat dan panduan praktikum densitas menggunakan model pembelajaran inkuiri terbimbing pada kuliah fisika dasar 1 topik tekanan hidrostatis. Jurnal Sains, Matematika dan Edukasi Fisika FMIPA UNIMA.

Muhson, A. (2010). Pengembangan Media Pembelejaran Berbasis Teknologi Informaasi. Jurnal Pendidikan Akuntasi Indonesia, 1-10.

Sugiyono. (2016). Metode Penelitian Kualitatif, Kuantitatif dan $R \& D$. Bandung.

Tulandi, D., \& J Lolowang (2019). Desain dan Uji Keberfungsian Alat Praktikum Fluida Dinamis. Jurnal Sains dan Teknologi, Universitas Negeri Manado. 